Andrzej Pisowicz

UNIWERSYTET JaGIELLOŃSKi, KRAKów

\title{
WSPOMNIENIE O WARTANIE GRIGORIANIE
}

\begin{abstract}
Abstrakt: Autor opisuje swoje kontakty i przyjaźń z doktorem Wartanem Grigorianem, wybitnym specjalistą ormiańskim z zakresu dziejów diaspory w Polsce, datujące się na lata 1962-2012. Omawia jego dorobek twórczy oraz postawę patriotyczną na tle wydarzeń w Armenii.
\end{abstract}

Slowa kluczowe: Wartan Grigorian, Andrzej Pisowicz

W 1962 roku przebywałem w Erywaniu na dwuletnim kursie filologii ormiańskiej (po czterech latach studiów iranistycznych na Uniwersytecie Jagiellońskim). Mieszkałem w domu akademickim przy alei Stalina 52, przemianowanej wkrótce na aleję... Lenina (obecnie: Mesropa Masztoca). Z owego „akademika” było blisko do Matenadaranu, oddanego do użytku w 1957 roku „Muzeum Dawnych Rękopisów". Tam poznałem Wartana Grigoriana, historyka, pracownika naukowego owego muzeum (później był jego wicedyrektorem). Co ciekawe, to nie ja go szukałem (bo byłem filologiem, nie historykiem), tylko on (starszy ode mnie o 11 lat) - mnie. Bo zajmował się historią polskich Ormian i potrzebował pomocnika znającego lepiej język polski niż on sam, dopiero wówczas rozpoczynający naukę naszego języka.

I zaraz zaproponował mi współpracę, przyczyniając się do przygotowania przeze mnie pierwszej publikacji. Mianowicie udostępnił mi kopię przechowywanego w Matenadaranie tekstu sądowego z 1573 roku. Był on zredagowany w języku polskim, ale notowany literami alfabetu ormiańskiego, bo pewnej grupie polskojęzycznych Ormian z kresów południowowschodniej Rzeczypospolitej tak widocznie było wtedy najłatwiej przygotować dokument. Znając pismo ormiańskie, rozszyfrowałem ów polski tekst i razem z Wartanem Grigorianem opu- 
blikowaliśmy artykuł $\mathrm{w}$ języku ormiańskim pod tytułem Zujuunun jthhtplí ¿uulthuiqtipn [Dokumenty polskojęzyczne spisane alfabetem ormiańskim] w roczniku „Fuupten Uuuntiqunupuin”” (tytuł rosyjski: „Вестник Матенадарана"), tom 7, Erywań 1964, s. 225-236, ze streszczeniem w językach rosyjskim i francuskim.

Wartan był bardzo sympatyczny i życzliwy. Zapraszał mnie często do swojego starego domu i przyjmował z typową dla Ormian gościnnością. Wiele skorzystałem z rozmów, które prowadziłem z Nim oraz z Jego Małżonką Hasmik (zmarła wiele lat przed swym mężem). Pamiętam też ich małego (wówczas) synka o imieniu Aram, który później zrobił karierę dyplomatyczną w niepodległej Republice Armenii.

Zmarły 28 marca 2019 roku Wartan Grigorian swoje imię (nawiązujące do bohatera walk z Persami z połowy V wieku, Wartana Mamikoniana) zawdzięczał... sobie. Zmienił je jako dorosły już mężczyzna. Rodzice dali mu inne imię po urodzeniu (w 1929 roku): miał być Władimirem na cześć wielkiego wodza rewolucji październikowej, czczonego w Związku Sowieckim jeszcze długo. Ta zmiana wymagała nie lada odwagi w czasach sowieckich: rezygnacja z zaszczytnego imienia twórcy imperium światowego proletariatu na rzecz imienia narodowego bohatera ze starożytności (i to kojarzonego z obroną chrześcijaństwa) było odbierane w sowieckiej Armenii jako przejaw nacjonalizmu. Ale jednak Władimir Grigorian zrealizował swój plan i zmienił sobie oficjalnie imię. Do dokumentów wpisano mu: Wartan (w historycznej pisowni ormiańskiej: Wardan, પuunqu氏).

Nie zerwałem kontaktów z moim Przyjacielem po powrocie do Krakowa w 1963 roku. Korespondowaliśmy ze sobą, a prócz tego nieraz się spotykaliśmy, bo Wartan przyjeżdżał kilka razy do Krakowa na czele wycieczek członków Towarzystwa Przyjaźni Radziecko-Polskiej z Erywania (odpowiednik polskiego Towarzystwa Przyjaźni Polsko-Radzieckiej).

Gdy przyjechał do Polski w 1965 roku, podzielił się ze mną niezwykle ważnymi wiadomościami, których - ze względu na cenzurę - nie mógł zamieścić w liście posyłanym oficjalną pocztą. Mianowicie opisał mi szczegółowo, w bardzo emocjonalnej opowieści, wielki wstrząs społeczny, który przyniosły nielegalne erywańskie obchody 50-lecia ludobójstwa popełnionego w 1915 roku na Ormianach w Turcji (Armenia Zachodnia do dziś leży na terenie Republiki Turcji).

24 kwietnia 1965 roku na ulice Erywania wyszły wielotysięczne thumy. Bez zezwolenia władz, bo kultywowanie pamięci o tragedii 1915 roku było przez władze sowieckie traktowane jako przejaw nacjonalizmu (tylko Rosjanom nie groził zarzut popełnienia czynu z tego ,paragrafu”). Ormianie okazali jednak odwagę i na ulicach swej stolicy rozwinęli transparenty czczące pamięć rodaków pomordowanych lub zmarłych z głodu czy też w następstwie chorób, na które zapadali podczas „marszów śmierci” do doliny Dajr az-Zaur w Syrii. Być może manifestantom dodawała odwagi świadomość, iż nie protestują przecież przeciw 
władzy radzieckiej (za co mogliby oczywiście od razu pójść za kratki), ale jedynie czczą pamięć rodaków, którzy zginęli w kapitalistycznej, a więc wrogiej, Turcji. Cóż w tym złego? A jednak - tłumy zostały rozpędzone, a uczestnicy manifestacji byli szykanowani.

Władze lokalne zostały przez Moskwę ukarane utratą wielu stanowisk za dopuszczenie do nielegalnych pochodów. Ale odwaga mieszkańców Erywania przyniosła nieoczekiwany pozytywny skutek. Kreml zorientował się, że dla Ormian pamięć ludobójstwa 1915 roku jest czymś niezwykle ważnym. Można by powiedzieć, że czymś w rodzaju tragicznego, wtórnego mitu założycielskiego narodu ormiańskiego. I centralne władze sowieckie wyraziły zgodę na budowę monumentalnych obiektów czczących pamięć ofiar ludobójstwa. Na poderywańskich wzgórzach tak zwanego Cicernakaberdu, to jest Twierdzy Jaskółczej (na które chodziłem się opalać trzy lata wcześniej) wzniesiono imponujące budowle upamiętniające ofiary ludobójstwa. W ich pobliżu posadził swoje drzewko także nasz papież, Jan Paweł II, przybyły do Erywania z okazji 1700-lecia chrześcijaństwa Armenii w 2001 roku. A w 1968 roku w odległości około 60 kilometrów na zachód od Erywania zbudowano piękny kompleks pomników upamiętniających zwycięską bitwę pod Sardarapatem (22-26 maja 1918), w której bohaterscy żołnierze (pierwszej) niepodległej Republiki Armeńskiej powstrzymali armię turecką grożącą zagładą dopiero co odrodzonej niepodległej Armenii.

O wydarzeniach z końca kwietnia 1965 roku z przejęciem opowiadał mi Wartan parę miesięcy później, podczas krótkiego pobytu w Krakowie. A ja przekazywałem opowieści w środowisku krakowskich Ormian i ich przyjaciół. Co ciekawe, pamięć o tych wydarzeniach nie jest w Armenii tak trwała, jak by się można spodziewać. Wielu, zwłaszcza młodym, Ormianom wydaje się, że kompleks memorialny na wzgórzach Cicernakaberdu stoi tam od niepamiętnych czasów. Gdy była o nim mowa podczas uroczystej konferencji w Librarii Collegium Maius w Krakowie, powołującej do życia 21 września 2019 roku Ośrodek Badań nad Kulturą Ormiańską w Polsce, padła, owszem, data decyzji podjętej przez władze Związku Sowieckiego o budowie kompleksu memorialnego (rok 1965), ale żadna wzmianka nie przypomniała słuchaczom, jakie wydarzenia wymusiły tę decyzję. A szkoda.

Kolejnym dowodem przyjaźni łączącej mnie z Wartanem Grigorianem było zaproszenie, które przysłał mi w 1970 roku. Na jego podstawie mogłem pojechać do Erywania w celu zbierania materiałów do pracy doktorskiej. Przez dwa tygodnie mieszkałem wówczas w nowym mieszkaniu państwa Grigorianów przy ulicy Barekamutian. Nie zapomnę serdecznej gościnności, jaką mi wówczas okazywali oboje: Wartan i Hasmik.

Rozprawa kandydacka (odpowiednik polskiego doktoratu) Wartana Grigoriana dotyczyła polskich Ormian. Została opublikowana po rosyjsku, dzięki czemu 
mogli się z nią zapoznać nie tylko ormiańscy, ale i polscy historycy. Nosiła tytuł: История армянских колоний Украины и Польши (армяне в Подолии) (1980).

Po raz ostatni widziałem Wartana we wrześniu 2012 roku, gdy wraz z żoną przyjechałem do Erywania. Razem zjawiliśmy się w mieszkaniu przy ulicy Barekamutian. Wartan był fizycznie osłabiony po wylewie, który wcześniej zrujnował mu zdrowie, ale umysłowo i psychicznie był w dobrej formie. Wspominaliśmy nasze kontakty i cieszyliśmy się z niepodległości, którą Armenia po raz drugi uzyskała w 1991 roku.

\section{Andrzej Pisowicz, Memories of Vartan Grigoryan}

Summary: The author describes his contacts with Vartan Grigoryan, an outstanding Armenian specialist in the history of the diaspora in Poland, dating from 1962-2012. He discusses the researcher's creative output and patriotic attitude.

Keywords: Vartan R. Grigoryan, Andrzej Pisowicz

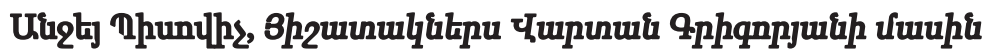

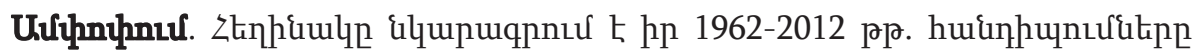

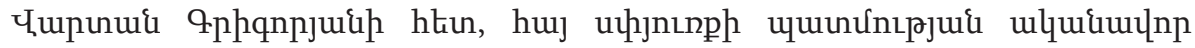

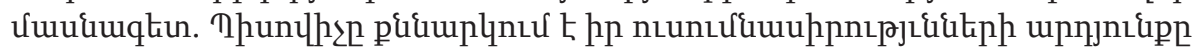

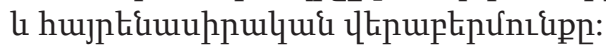

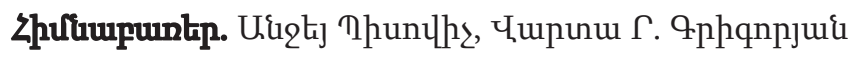

